\title{
The American Community College: A Predictable and Unpredictable Future
}

\author{
Jeff Scaggs, Ed.S. \\ Central Piedmont Community College \\ Charlotte, NC, USA \\ Jenn Scaggs, Ed.S. \\ Central Piedmont Community College \\ Charlotte, NC, USA
}

\begin{abstract}
A literature review consisting of scholarly articles, books, and past and present interviews of college faculty, staff, students, and businesses was drafted on the future trends of higher education. Specifically, some past and present predictable trends, such as developmental education, data-driven decision-making, technology, accountability, advising methods, and accessibility were reviewed and expanded upon, as all will continue to affect higher education for the next several decades. A few new and somewhat unpredictable trends including, flipped classrooms, learning analytics, Competency-Based Education, open educational resources, and individualized learning pathways were mentioned.
\end{abstract}

Keywords: future of higher education, higher education accessibility, educational accountability, workforce development, student success, technology, data mining, flipped classrooms, data-driven leadership

Community colleges in America are presently facing several crises, many of which will undoubtedly continue to affect community colleges for the next 20 and even 50 years, as several have already been central foci for past decades. Over the next 50 years, American community college leaders will need to persist with the continual revamping and redesign of developmental education, as developmental education is here to stay(Community College Research Center, 2014);remain aware of the effect of globalization on education and workforce development; hire and maintain globally competent leaders; continue to improve graduation rates, which remain rather dismal; focus on both student access and student success; continue to rely on data-driven decision-making and leadership (American Association of Community Colleges, 2013). Additionally, over the next half-century, community colleges are going to have to address such issues as learning analytics and predictive algorithms for the prediction of student success, individualized learning pathways, Competency Based Education (CBE), open educational resources, updated articulation agreements between community colleges and universities, streamlined advising models and one-stop advising for students, flipped classrooms, the rise and ultimate dependence on online learning as a primary instructional mode (J. Jensen, personal communication, June 15, 2016), and corporate universities (Mintz, 2014).

Unfortunately, due to high tuition costs, the opportunity for higher education is not within reach for many Americans. The American community college has a distinct advantage in that tuition is much more affordable than that of baccalaureate granting institutions. Moreover, community colleges operate by way of an open door admissions policy, thus allowing for greater accessibility (American Association of Community Colleges, 2013).By the end of the current decade, 2020, roughly $42 \%$ of current community college presidents across the nation will be retired (Aspen Institute, 2013). Consequently, a new incoming class of college leaders will guide the missions and visions of community colleges for decades to come. Per emerging educational trends expected to influence and shape higher education for the next several decades, rising college presidents and senior administrators must be global leaders, as external partnerships with both local and global organizations will continue to be imperative to the missions and success of community colleges, as well as, to the success of all future students (VanderPal, 2014).

\section{Accessibility}

Though the door is open in terms of admissions, the door may close a bit over the next several decades. Given that the present graduation rate for community colleges is quite low, as only $46 \%$ of students enrolled in community college graduate from community college or transfer to a four-year baccalaureate granting institution (American Association of Community Colleges, 2013), the solicitation and use of accreditation information of secondary schools might allow community colleges the ability to create more specific intervention programs for their underprepared student population. Such information may be relevant to student success and academic placement (Mintz, 2014). 
For instance, such information may be of value to specific academic and professional programs, and may even be relevant to the accreditation rules of those programs. Also, community colleges will have a greater pool of highly qualified applicants for both general admissions to the college and specific programs of study. Community colleges will become competitive. Community colleges will be able to develop and offer new programs traditionally offered by colleges and universities (Campbell, n.d.). According to Campbell (n.d.), community colleges in Florida are evolving to adopt a dual role in higher education, a role as a community college offering associate degrees and a role as a fouryear college offering bachelor degrees. As a result, community colleges will likely become more selective, and the missions of community colleges and baccalaureate granting institutions will begin to parallel one another. The American community college of the future will offer baccalaureate degrees in addition to certificates, diplomas, and associate degrees (Campbell, n.d.).

\section{Advising}

The current academic advising model used by the majority of community colleges is grossly outdated and futile (O'Banion, 2013). O'Banion (2013) noted that the often one-time advising event for students typically used by colleges is not sufficient for the enhancement of student success, and should instead, be replaced by a flexible and continuous advising model. A modern advising model should be implemented even before students step foot into their first college class, and continueuntil students graduate or transfer out to other colleges and universities. Per O'Banion (2013), a continuous academic advising model will unquestionably guide students successfully through the process of academic advising; "Academic advising is the second most important function in the community college" (O'Banion, 2013, p. 3). Continuous academic advising is critical to a student's exploration and eventual selection of vocational and life goals by way of the completion of a relatively prescribed program of study (O'Banion, 2013).

As a current successful model for the future of advising, Stanly Community College's (SCC) advising model mirrors the future trend of advising as being a one-stop and continuous model for students, advisors, and faculty members (M. Furr, personal communication, October 9, 2015). Dr. Myra Furr, Associate Vice President of Student Success and Dean of Students at SCC, referred to SCC's advising center as the Eagles One-Stop Advising Center. According to Dr. Furr, the Eagles One-Stop Advising Center is in its fourth year and is what is termed a "mixed methods" advising center (personal communication, October 9, 2015). Students are required to meet with their program advisor for the first 30 hours of their program and communicate with the College's advising center and program/faculty advisors via face-to-face meetings, phone, email, or the most popular mode - Skype. After the completion of 30 credit hours, students are free to continue communicating with their program advisor or the Eagles One-Stop Advising Center; it is a student's choice (M. Furr, personal communication, October 9, 2015). Dr. Furr mentioned that students and staff are able to keep track of a student's academic plan using a new mapping feature, known as Student Success Plan (SSP). Thus, counselors in the Eagles One-Stop Advising Center are easily able to communicate with both program/faculty advisors and students allowing for data-driven leadership (M. Furr, personal communication, October 9, 2015). Dr. Furr stated that a holistic and continuous virtual one-stop advising center is the future trend of advising (personal communication, October 9, 2015).

\section{Human Capital}

As reported by Darden (2009), education is highly influenced by knowledge-based economies. In a knowledge-driven culture, the need for the development of human capital is the responsibility of higher education (Darden, 2009). In particular, community colleges advance and nourish the development of human capital for traditional students and nontraditional students, such as first-generation college students and students of lower SES. "The vocational success of community college students depends largely on the job opportunities that become available and the number and skills of other applicants for the same position" (Romano \& Kasper, 2009, p. 3). Supporting human capital, local employers reach out to their local community colleges for viable job candidates (Romano \& Kasper, 2009).

\section{Athletics}

Just as with universities, community colleges are beginning to recognize the importance of a holistic approach to the human growth and development of all students. Thus some community colleges throughout the nation are now promoting the intellectual, physical, and social growth of their students (Darden, 2009). As a way to not only increase enrollment, but to foster human growth, many community colleges have delved into varsity sports. As an example, Iowa Central Community College has placed a rather significant emphasis on varsity sports as a means to enhance student success and increase enrollment by attracting nontraditional community college students that may otherwise have attended a university following their high school graduation. Athletics will become part of the community college student experience over the course of the next several decades (Elyse, 2007). 


\section{Technology}

Technology and information systems are forcing change, and are affecting college fundraising campaigns (Milliron, de los Santos, \& Browning, 2003), instruction, data processing, transparency among institutions, and the prediction of student success via learning analytics and data mining (Zacharoula, \& Anastasios, 2014). Information systems include many different systems used to acquire various types of information. One type of information system is a management information system (MIS), or information management system (IMS) (Boykin, n.d.). Inc (2015) defined a MIS as "a computerized database of financial information organized and programmed in such a way that it produces regular reports on operations for every level of management in a company" (p. 1). Thus, the central purpose of all information systems, including MIS/IMS, is the collection of data and feedback of performance-related information for an organization. Top-level management most often has access to these routine reports (Inc, 2015). Inc (2015) noted that although practically all organizations and businesses use computers, not all have begun to use MIS/IMS.

\section{Information management systems}

As educational institutions, community colleges rely on various IMS in an attempt to build a culture characterized by data-driven decision-making, data-driven leadership, and transparency (G. Ritter, personal communication, June 23, 2016). As independent learning institutions, all 58 community colleges in the North Carolina Community College System (NCCCS) have the ability to select the IMS of their choice; the NC Community College System Office does not mandate which IMS NC community colleges should adopt. As in other states, both advantages and disadvantages of such an autonomous system for the procurement and use of IMS by community colleges are being discussed (G. Ritter, personal communication, June 23, 2016).

The current self-governing nature of IMS purchases by NC community colleges and the lack of standardization of required IMS by the NC Community College System Office allows for several advantages. For instance, each community college may lead and serve its respective community via the technology and frame most appropriate for the needs of the community (Bolman \& Deal, 2013). Moreover, Nicastro (2013) and Solomon (2013) mentioned the importance of the relationship between an organization's chosen IMS and the goals and vision of the organization. "If the customer and the vendor are aligned, then the desirable features will continually be added and the product will grow with the customer" (Nicastro, 2013, p. 1). An organization's ability to select the IMS of its choice allows the organization to have greater insight in to how the organization can better serve its customers, as the organization has taken the necessary time to explore and research all options in an effort to make a valid selection (Nicastro, 2013). Further, when allowed to choose an IMS specific to an organization's needs, the organization will likely select the optimal IMS for its purposes (Regli, 2010). Since the organizational structure of the NCCCS is characteristic of a divisionalized structural configuration, the NC Community College System Office has limited control and supervision over individual colleges. Thus, autonomous IMS purchases seem ideal for the NCCCS (Bolman \& Deal, 2013).

Other advantages of autonomous IMS purchases for NC community colleges include increased institutional efficiency and productivity, increased intra-campus communication, decreased state responsibility for IMS maintenance, and the identification, advocacy, and backing of a cohesive college culture via an appropriate cultural frame of organizational development — structural, human resources, political, and symbolic (Bolman \& Deal, 2013). Consequently, the need for second-order changes due to IMS is lessened. Conversely, the prevalence of first-order changes is increased, thus abating large-scale organizational change (Bolman \& Deal, 2013).

A significant disadvantage of an autonomous system with regard to IMS and technology purchases is the lack of standardization of IMS for community colleges in any particular state (Bolman \& Deal, 2013). As a result, there is a decrease in overall inter-campus communication. By the same token, such an independent IMS policy creates distinct technology-based cultures for each community college (Bolman \& Deal, 2013). Therefore, there is an overall lack of transparency among colleges, which can potentially lead to a decline in both employee morale and commitment due to a nonexistent-shared culture for IMS and technology (Kezar, 2014). The consequences are increased costs for the state and for each college, decreased efficiency and productivity across the state, a greater incidence and prevalence of second-order institutional changes, and increased maintenance (Bolman \& Deal, 2013). Community colleges will experience multiframe conflict as each college is operating via different IMS. Therefore, conflict may result among campuses, as each college will be working via different lenses. For instance, administrators at one college may be using the political lens, while administrators at another college are using the human resources lens (Bolman \& Deal, 2013). Further, ambiguity and complexity, stemming from the use of multiple and different IMS, may negatively affect the overall performance of the state's community colleges (Bolman \& Deal, 2013). It is perhaps too soon to tell which direction colleges will go, but the authors predict that in 50 years community colleges will be using a chosen standardized state IMS as to promote transparency and accountability. 


\section{Course length and mode of delivery}

Because of technology, colleges must readdress and experiment with course format and delivery (Darden, 2009). Technology has led to new course formats, such as four-week, eight-week, and 12-week courses in lieu of the traditional 16-week semester model. "I am super excited about the possibility of taking shorter length classes. I can graduate early" (anonymous student, personal communication, May 9, 2016). Additionally, modes of course delivery have expanded to online and hybrid modules, allowing for greater instructor and student flexibility. Moreover, educational technology is redefining the job description of a faculty member, as open educational resources are becoming more prevalent and accepted among academics (Mintz, 2014).Professor Stephanie Sabbagh is becoming concerned as faculty are being asked to teach more and more online classes, and many are not adequately prepared to utilize the technology necessary to teach those classes (personal communication, May 6, 2016). Other faculty members embrace the opportunity to teach fully online. Dr. Anne McIntosh, of Communications, is ecstatic about the possibility of transitioning all of her face-to-face classes to online classes (personal communication, May 6, 2016). Moreover, students seem thrilled about the future offerings of more online classes (anonymous student, personal communication, May 9, 2016). An increase in online instruction over the next 20 to 50 years will result in "The Bare-Bones University" (Mintz, 2014, p. 3). That is, a limited number of majors, consisting of online classes, will be linked to employer needs. The future community college will not have a need for as much physical classroom space (Mintz, 2014).

\section{Flipped classrooms}

Flipped or inverted classes have also been more prevalent because of available technology, and the ability to retrieve instant feedback from students during a class discussion and activity. Acting in the role of instructor, students are now presenting material and teaching fellow classmates (Rotellar \& Cain, 2016). According to Rotellar and Cain (2016), inverted classes increase student engagement, enhance comprehension, and encourage students to interact more frequently with faculty members. Benjamin Franklin (as cited in Rotellar \& Cain, 2016) said, "tell me and I forget, teach me and I may remember, involve me and I learn" (p. 6). Over time, filipped classrooms will reshape and redfine current pedogies, as technology is providing students with the access to course content prior to a classroom lecture. Online classes are slowly morghing from a chalk and talk paradigmn to a flipped classroom design as well. It is expected that flipped classroom are here to stay (Rotellar\& Cain, 2016).

\section{Developmental Education}

In reference to the future of developmental education, Charles A. Dana Center Complete

College America (2012) reported:

This is no time for merely testing the waters or for treading water. We can do better and both research and practice point the way forward. The task that lies ahead is to put this knowledge together with an urgency to drive large-scale change -for the sake of millions of students and families who are counting on postsecondary education as the first step to a better future. (p. 12)

Approximately two-thirds of all employment positions in the United States by 2018 will require a postsecondary degree (American Association of Community Colleges, 2013). Forty-percent of African American students and students of low socioeconomic status (SES) enter the community college system below the threshold for college readiness. Efforts to reduce the inequalities among students by eliminating all barriers that are currently hindering student success are essential to student success centered academic institutions (Achieving the Dream, 2015). American community colleges are "the Ellis Island of American higher education" (American Association of Community College, 2013, p. 1). Being an open-door institution and one of the pillars of the American Dream, community colleges are faced with then need to reform. In an attempt to meet these goals, community colleges must reimagine and redesign the educational pathways of students; reinvent institutional roles; and reset the system, specifically, the status quo of developmental education (American Association of Community College, 2013). For years to come, community colleges must strive for quality while maintaining access (Fonte, 2006).

The model for developmental education of yesteryear is detrimental to student success. The customary practice of overly placing incoming students into developmental courses on the basis of an "over-reliance on rigid policies and procedures" (A Common Framework, 2013, p. 36) has been ineffective for student success, developmental education completion rates, and college completion rates (A Common Framework, 2013). The blame does not reside entirely on the shoulders of community colleges, as there are many other confounds that have an adverse impact on developmental education completion rates and the negative correlation between placement in developmental education and graduation rate. Within eight years of taking three developmental courses only $19 \%$ of students earn a bachelor's degree (Colleges Cope, 2009). Moreover, only one in four developmental education students will matriculate (Dowd, 2007). 
However, "remedial students at community colleges worked harder, visited their professors more often, and took greater advantage of college support services than did their better-prepared peers" (Evelyn, 2005). Instead, blame should be on the ineffective and invalid use of standardized assessments and single placement exams, traditionally employed by community colleges, to determine placement of students in developmental education courses. Moreover, blame can also be placed on the acceptance of the grossly exaggerated perception that the vast majority of all incoming students need the same prescription for developmental education, based on the results obtained from the standardized assessments. In reference to standardized tests for the basis of admissions to programs of study, Zwick (2007) stated, "only a crude, backward society would actively seek to limit opportunity in this manner" (p. 419). Standardized tests do not promote equity among students; a weak correlation exists between scores on standardized tests and future academic performance (Zwick, 2007). However, some states are placing an even greater emphasis on standardized test scores for placement into credit courses. For example, Kentucky requires specific scores on the ACT for community college students to be able to be placed in college-credit Math and English courses. If students fail to obtain the required American College Testing (ACT) scores, the students are then placed in developmental education courses (Changes in Kentucky's, 2009).

A new trend is emerging. In lieu of standardized tests for student placement into developmental education courses, colleges are utilizing multiple measures, such as high school grade point average, self-efficacy, and motivation as valid factors for placement decisions (Charles A. Dana Center Complete College America, 2012). The holistic approach to multiple measures shows promise. For example, high school grade point average appears to be a valid criterion for academic placement, as well as a predictor of future academic performance (Charles A. Dana Center Complete College America, 2012). As a cautionary statement for the use of high school grade point average for academic placement, colleges must question the existence and/or practice of grade inflation in secondary education. Fifty-nine percent of high school students found high school classes to be non-challenging, and reported that most classes were easy (Colleges Cope, 2009).

In reference to the future of developmental education, Koch, Slate, and Moore (2012) suggested incorporating technology and new software programs in developmental courses. Many community colleges in the nation, as well as in North Carolina, are now using software, such as MyMathLab, a Pearson product, for developmental Math classes. The results are encouraging. The future of developmental education rests on data-driven decision-making. Though the 21 st century is dependent on the use of data, the collection and analysis of data is relatively new for community colleges. Since 2004 both federal and state initiatives for student success have been conceptualized, all focused on student equity and the reduction of inequalities among students via the usage of data and measures of college accountability. Examples of data-driven student success initiatives include Achieving the Dream (AtD) and Completion by Design (CbD). Both have directly affected developmental education by enhancing completion rates (Community College Research Center, 2011; Dowd, 2007). This trend of data-driven decision-making will need to continue for decades to come.

\section{Data-Driven Decision-Making and Leadership}

Academia "succeeds or fails in both the quality of the information it collects, synthesizes, and distributes as well as the speed with which that transfer takes place" (Darden, 2009, p. xiii). With respect to the prioritization of data usage, community colleges, in an attempt to become better consumers of data, must increase efforts to gather and analyze data by expanding both the knowledge base and number of staff of their institutional research (IR) departments. Improving both IR departments and IT systems will allow for better data and research capacity, including data collection, data analysis, and disaggregation of data per gender, ethnicity, race, and socio economic status (SES). Such improvements and advances will better aid community colleges in their attempts to identify and decrease achievement gaps among students. Moreover, the targeted focus on data will yield novel ideas and initiatives aimed at the improvement of developmental education (Community College Research Center, 2014).

Community colleges are now on the path to becoming data-driven learning institutions, and student success has become a measurable criterion for institutional effectiveness. Data-driven decision-making and leadership will shape the future of how colleges address developmental education. As long as community colleges continue to have an open-door admission policy, developmental education will always be needed, as underprepared students will continue to flock to community colleges in the hope of achieving the American Dream.

\section{Globalization}

Community colleges were created to serve local communities (Treat \& Hagedorn, 2013). However, community colleges are recently being charged with educating and training tomorrow's global leaders (Aspen Institute, 2013). 
Also, the need for global leaders in senior-level administrative roles of community colleges is more important than ever (VanderPal, 2014), as community college leaders will prepare students to work in a global environment (Opp \&Gosetti, 2014). The present call for global community college leaders represents both a first and second order change in higher education. As a first order change, future community college leaders will have to continue to work and deal with certain existing structures while leading constituents, students, and colleges toward new global competencies (American Association of Community Colleges, 2013). Notwithstanding continued refinement resulting from a first order change of leadership, community colleges will also soon experience a second order change — incoming freshmen global leaders. The majority of current community college presidents are not global leaders (American Association of Community Colleges, 2013). The significant turnover of community college presidents and administrators by 2020 (Aspen Institute, 2013) and the demand for global leaders (Holk \& Seki, 2012) will shake the very foundation of higher education, as a new perspective and way of doing business will be required of community college leaders (Kezar, 2014). Globalization and student success in a global economy will become the central themes for the rebirth of the American community college for many decades to come (American Association of Community Colleges, 2013).

The globalization of the American community college is resulting in global competition for resources and services. College leaders must break free of the industrial factory model and embrace novel programs and policies that will result in educational transformation (Milliron, 2007). In doing so, leaders will serve students by recognizing new global challenges and improving job market readiness in a globally competitive world (Milliron, 2007). The first step in recognizing and understanding global challenges is to gain an awareness of, and develop an appreciation for, the leadership styles of various cultures.

Per Darden (2009), higher education's focus on human capital is also being driven by globalization. Higher education is not immune to the effects of globalization. With a flattening economy brought on by globalization, universities and community colleges are required to educate an increasingly diverse student population (Darden, 2009). Globalization has also put a spot light on technology; technology is contributing to the improvement of a more skilled and job-ready workforce. Moreover, technology is allowing for greater accessibility (Darden, 2009). Darden (2009) stated that technology has positively influenced the dissemination of information.

\section{Global leadership}

The call for global leaders in higher education, being fueled by the development of global leadership in the Western world, is bestowing future community college leaders with the responsibility of meeting the current challenges facing global leadership. According to Holt and Seki (2012), urbanization and population growth in Africa and Asia are affecting globalization and reshaping both the benefits and risks associated with globalization. Globalization is fueling global competition, and very few organizations are immune to the effects of globalization and the flattening global environment. Therefore, the study and understanding of global leadership is of importance to the understanding of globalization (Holt \& Seki, 2012). Holt and Seki (2012) asked, "What is Global Leadership" (p. 196). Holt and Seki (2012) defined a global leader as "anyone who operates in a context of multicultural, paradoxical complexity to achieve results in our world" (p. 199) and argued that the majority of today's leaders are essentially global leaders. "We believe a huge shift is underway that will ultimately define all leaders as global leaders" (Holt and Seki, 2010, p. 198). Global leadership in higher education represents a second order change for community colleges, and a departure from a traditional local focus (Kezar, 2014). Over the next 20 years, community colleges will need to partner with national and global businesses for survival and competitiveness (A. McIntosh, personal communication, June 2, 2016).

\section{Workforce Development}

The establishment of robust partnerships with local, regional, and even national businesses has become important for the strategic planning and operational strategies of many community colleges in the 21 st century, and will continue to be of greater importance as time moves forward (Spangler, 2002). The flexibility of community colleges allows community colleges to offer both non-credit and job-specific courses for workforce training and development (Spangler, 2002). Community colleges are adept at building partnerships with neighboring educational institutions and government organizations to advance support and collaboration (Spangler, 2002), and academic and training programs and policies offered in isolation by community colleges are no longer ideal or beneficial for collaborative partnerships with other institutions and businesses (Cohen, Brawer, \& Kisker, 2014). For future accountability, community colleges must be held liable for their own institutional performance, which will be required to be both measurable and evidencebased. Transparency among institutions is imperative (American Association of Community College, 2013), especially when partnering with businesses for the achievement of collaborative goals benefiting both the college and the community the college serves (Spangler, 2002). 
Businesses look to community colleges for job-specific training (Spangler, 2002).In the coming decades, community colleges will need to partner with global business entities; continual involvement among all parties promotes "a natural exchange of needs" (Spangler, 2002, p. 22).

\section{Competency-Based Education}

"Calls for an outcomes-driven education geared toward 100 percent proficiency are giving traction to competencybased approaches that award credit for mastery rather than credit hours" (Mintz, 2014, p. 2). Garfolo and L'Huillier(2016) noted, "CBE moves education from an academic focus to a workplace focus" (p. 97); "what graduates need to know from an academician's point of view" (p. 97) to "what graduates need to know and do in a variety of complex workplace situations" (p. 97). Receiving credit for professional experience and past credentials will accelerate student completion rates, and though practiced primarily by for-profit educational institutions, non-profit schools are beginning to experiment with CBE (Mintz, 2014). Mintz (2014) further noted that CBE is career focused and will become a way of education for the future of colleges. Thus, CBE will still likely be around in 2036.

Pushed by technology, globalization, and a knowledge-driven society, higher education will be forced to shift paradigms and "emphasize cyberspace over floor space, electronic data over paper, and virtual instruction will eclipse face-to-face instruction" (Darden, 2009, p. 216). The paradigm shift will be representative of an institution of higher education in year 2036, and even more so, in year 2066. "The university of the past, historically linked to the community and region, will be of necessity shifting its sights to the global horizon" (Darden, 2009, p. 216). Community colleges will not only need to expand globally via mode of instruction and course offerings, but must simultaneously continue to forge partnerships with local business. After all, community colleges were designed to serve local communities. As community colleges begin to offer baccalaureate degrees, community colleges are still acknowledging the importance of workforce training and development, accessibility, accountability, and human capital. It is the author's opinion that community colleges will forever hold a special place in academia, as community colleges are the go-to preference of choice for local and regional businesses for workforce development and training.

\section{References}

Achieving the Dream (2015). Retrieved from http://www.achievingthedream.org

American Association of Community Colleges (2013). AACC competencies for community College leaders (2nd ed.). Retrieved from http://www.aacc.nche.edu/newsevents/Events/leadershipsuite/Documents/AACC_Core_ Competencies_web.pdf

Aspen Institute (2013). Crisis and opportunity: Aligning the community college presidency with student success. Retrieved from http://www.aspeninstitute.org/sites/default/files/content/docs/pubs/CEP_Final_Report.pdf

Bolman, L. \& Deal, T. (2013). Reframing organizations: Artistry, choice, and leadership. San Francisco, CA: JosseyBass.

Boykin, G. (n.d.). The difference between information system and management information system. Retrieved from http://www.ehow.com/facts_6869442_difference-system-management-information-system.html

Campbell, D. F. (n.d.). Future of the community college baccalaureate. Retrieve from http://www.statedirectors.org/Reports/Future_of_the_Community_College\%20Baccalaureate.pdf

Changes in kentucky's admission standards to impact developmental education. (2009). Journal of Developmental Education, 33(2), 44. Retrieved from http://ezproxy.cpcc.edu/login?url=http://search.proquest.com /docview/ 846785660 ?accountid $=10008$

Charles A. Dana Center Complete College America, Inc. Education Commission of the States

Jobs for the Future. (2012). Core principles for transforming remedial education: A joint statement. Retrieved from http://www.jff.org/publications/core-principles-transforming-remedial-education-joint-statement

Cohen, A. M., Brawer, F. B., \& Kisker, C. B. (2014). The american community college. $6^{\text {th }}$ ed. San Fransico: John Wiley \& Sons.

Colleges cope with rising demand for remedial courses. (2009). American Teacher, 93(4), 7. Retrieved fromhttp://ezproxy.cpcc.edu/login?url=http://search.proquest.com/docview/217248523?accountid=10008

A common framework for remedial reporting. (2013). Journal of Developmental Education, 37(2), 36. Retrieved from http://ezproxy.cpcc.edu/login?url=http://search.proquest.com/docview/1555952912?accountid=10008

Community College Research Center (2011). Turning the tide: Five years of achieving the dream in community colleges. Retrieved from mdrc website: http://www.mdrc.org/sites/default/files/full_593.pdf

Community College Research Center (2014). Moving ahead with institutional change: Lessons from the first round of achieving the dream community colleges. Retrieved from mdrc website: http://www.mdrc.org/sites/default/files/moving_ahead_with_institutional_change_fr_0.pdf 
Darden, M. L. (2009). Beyond 2020: Envisioning the future of universities in America. New York, NY: American Council on Higher Education.

Dowd, A. C. (2007). Community colleges as gateways and gatekeepers: Moving beyond the access "saga" toward outcome equity. Harvard Educational Review, 77(4), 407-419,528. Retrieved from http://ezproxy.cpcc.edu/login?url=http://search.proquest.com/docview/212291440?accountid=10008

Elyse, A. (2007). To increase enrollment, community colleges add more sports. Chronical of Higher Education, 53(44), A31.

Evelyn, J. (2005). Remedial students at 2-year colleges work harder than their peers, survey finds. The Chronicle of Higher Education, 52(13), A38. Retrieved from http://ezproxy.cpcc.edu/login?url=http://search.proquest.com/ docview/214684623? accountid $=10008$

Fonte, R. (2006). Open access with limits. The Chronicle of Higher Education, 52(25), B14.

Retrieved from http://ezproxy.cpcc.edu/login?url=http://search.proquest.com/docview/214672547? accountid= 10008

Garfolo, B. T., \& L'Huillier, B. (2016). Competency based education (CBE): Baby steps for the United States. Academy Of Business Research Journal, 197-113.

Holt, K., \& Seki, K. (2012). Global leadership: A developmental shift for everyone. Industrial \& Organizational Psychology, 5(2), 196-215. doi:10.1111/j.1754-9434.2012.01431.x

Inc. (2015). Management information systems (MIS). Retrieved from http://www.inc.com/encyclopedia/managementinformation-systems-mis.html

Kezar, A. (2014). How colleges change: Understanding, leading, and enacting change. New York: Routledge.

Koch, B., Slate, J. R., \& Moore, G. (2012). Perceptions of students in developmental classes. The Community College Enterprise, 18(2), 62-82. Retrieved from http://ezproxy.cpcc.edu/login?url=http://search.proquest.com /docview/1287963088?accountid=10008

Milliron, M. D. (2007). Transcendence and globalization: our education and workforce development challenge. New Directions for Community Colleges, (138), 31-38.

Milliron, M. D., de los Santos, G. E., \& Browning, B. (2003). Feels like the third wave: The rise of fundraising in the community college. New Directions For Community Colleges, 2003(124), 81-93.

Mintz, S. (2014). The future of higher education. Inside Higher Education, 1-8.

Nicastro, D. ( 2013). 7 rules for selecting the right content management system. Retrieved from http://www.cmswire.com/cms/web-cms/7-rules-for-selecting-the-right-content-management-system023026.php

O'Banion, T. (2013). Academic advising: The key to student success. Washington: DC. American Association of Community Colleges.

Opp, R. D., \& Gosetti, P. P. (2014). The role of key administrators in internationalizing the community college student experience. New Directions For Community Colleges, 2014(165), 67-75.

Regli, T. (2010). How to choose a website content management system. Retrieved from http://www.inc.com/guides/choose-website-content-management-system.html

Romano, R. M. \& Kasper, H. (2009). Occupational outlook for community college students. San Francisco, CA: Jossey-Bass.

Rotellar, C., \& Cain, J. (2016). Research, perspectives, and recommendations on implementing the flipped classroom. American Journal of Pharmaceutical Education, 80(2), 1-9.

Solomon, J. (2013). Six important factors to consider before choosing a technology. Retrieved from http://www.slideshare.net/coloradostatelibrary/six-important-factors-to-consider-before-choosing-atechnology-jon-solomon

Spangler, M. S. (2002). Developing successful partnerships with business and community. New directions for community colleges. San Francisco, CA: Jossey Bass. Retrieved from http://eric.ed.gov/?id=ED472019

Treat, T., \& Hagedorn, L. S. (2013). Resituating the community college in a global context. New Directions For Community Colleges, 2013(161), 5-9.

VanderPal, G. (2014). Global leadership, IQ and global quotient. Journal of Management Policy \& Practice, 15(5), 120-134.

Zacharoula, P., \& Anastasios A., E. (2014). Learning analytics and educational data mining in practice: A systematic literature review of empirical evidence. Journal of Educational Technology \& Society, (4). 49.

Zwick, R. (2007). College admissions in twenty-first-century-america: The role of grades, tests, And games of chance. Harvard Educational Review, 77 (4), 419-428. Retrieved from http://ezproxy.cpcc.edu/login?url=http://search.proquest.com/docview/212291440?accountid=10008 